University of Nebraska - Lincoln

DigitalCommons@University of Nebraska - Lincoln

USDA National Wildlife Research Center - Staff Publications
U.S. Department of Agriculture: Animal and Plant Health Inspection Service

July 2001

\title{
SURVIVAL OF AVIAN CARCASSES AND PHOTOGRAPHIC EVIDENCE OF PREDATORS AND SCAVENGERS
}

Richard M. Kostecke

North Dakota State University, Fargo

George M. Linz

USDA/APHIS/WS National Wildlife Research Center, george_m_linz@yahoo.com

William J. Bleier

North Dakota State University, Fargo

Follow this and additional works at: https://digitalcommons.unl.edu/icwdm_usdanwrc

Part of the Environmental Sciences Commons

Kostecke, Richard M.; Linz, George M.; and Bleier, William J., "SURVIVAL OF AVIAN CARCASSES AND PHOTOGRAPHIC EVIDENCE OF PREDATORS AND SCAVENGERS" (2001). USDA National Wildlife Research Center - Staff Publications. 510.

https://digitalcommons.unl.edu/icwdm_usdanwrc/510

This Article is brought to you for free and open access by the U.S. Department of Agriculture: Animal and Plant Health Inspection Service at DigitalCommons@University of Nebraska - Lincoln. It has been accepted for inclusion in USDA National Wildlife Research Center - Staff Publications by an authorized administrator of DigitalCommons@University of Nebraska - Lincoln. 


\title{
SURVIVAL OF AVIAN CARCASSES AND PHOTOGRAPHIC EVIDENCE OF PREDATORS AND SCAVENGERS
}

\author{
RicHARD M. KOSTECKE ${ }^{1}$ \\ Department of Zoology, Stevens Hall \\ North Dakota State University \\ Fargo, North Dakota 58105-5517 USA \\ GEORGE M. LINZ \\ U.S. Department of Agriculture, National Wildlife Research Center \\ Great Plains Field Station, 2110 Miriam Circle, Suite B \\ Bismarck, North Dakota 58501-2502 USA \\ WiLliam J. BLeier \\ Department of Zoology, Stevens Hall \\ North Dakota State University \\ Fargo, North Dakota 58105-5517 USA
}

\begin{abstract}
Scavenging of carcasses may bias estimates of mortality following the use of pesticides. To assess carcass survival, we monitored bird carcasses in crop stubble, grassland, roadside, and wooded habitats in east-central South Dakota in early spring. Survival rates differed among habitat types in 1997 but not in 1998. Survival rates did not differ among species of carcass in 1997 or 1998 . Within 5 d, $66 \%$ of carcasses had been scavenged in both 1997 and 1998. To assess potential hazards of secondary poisoning, we used infrared-triggered camera systems to identify predators and scavengers of live birds and bird carcasses. Mammals $(n=164)$, particularly striped skunks (Mephitis mephitis) $(n=105)$, were the most commonly photographed predators and scavengers. The number of avian predators and scavengers photographed $(n=39)$ was relatively low. Because scavenger activity can be high, we recommend that searches for carcasses should be conducted within $24 \mathrm{~h}$ of pesticide application to ensure accurate estimates of mortality.
\end{abstract}

\section{“SUPERVIVENCIA" DE CADÁVERES DE AVES Y EVIDENCIA FOTOGRÁFICA DE DEPREDADORES Y CARROÑEROS}

Sinopsis.-El carroñeo de cadáveres puede viciar los estimados de mortalidad causados por pesticidas. Para evaluar la "sobrevivencia" de cadáveres, monitoriamos los cadáveres de aves en remanentes de siembras, yerbasales, servidumbre de pasos de carreteras y habitat con árboles durante la primavera. El estudío se llevó a cabo en la parte este Central de Dakota del sur. La tasa de sobrevivencia resultó diferente entre los diferentes tipos de habitat estudiado en 1997, pero no así en 1998. No hubo diferencia en las tasas de "sobrevivencia" de los cadáveres de las diferentes especies en 1997 y 1998. En ambos años el 66\% de los cadáveres fueron eliminados por los carroñeros en un período aproximado de cinco días. Para determinar los peligros potenciales de venenos secundarios utilizamos un sistema de cámara disparados por las emanaciones infrarojas de los organismos, para poder identificar los depredadores y carroñeros de aves vivas y cadáveres, respectivamente. Mamíferos $(n=164)$, particularmente Mephitis mephitis $(n=105)$ fueron los depredadores y carroñeros más comúnmente fotografiados. El número de aves depredadoras y carroñeras fotografiados resultó ser sumamente bajo $(n=39)$. Dado el caso de que la actividad de los carroñeros puede ser sumamente alta recomendamos a los investigadores conducir una busqueda de cadáveres dentro de las 24 horas de la aplicación de pesticida. Esto asegurará en gran medida estimados precisos.

${ }^{1}$ Current address: Department of Range, Wildlife, and Fisheries Management, Texas Tech University, Lubbock, Texas 79409-2125 USA. 
Potential negative impacts associated with pesticide use are a major concern to wildlife resource managers (Balcomb 1986; Tobin and Dolbeer 1990; Linz et al. 1991, 1998; Tome et al. 1991). Reliable estimates of target and nontarget mortality are needed to assess efficacy and risk, respectively. However, scavenging may bias mortality estimates (Humberg et al. 1983; Balcomb 1986; Stutzenbaker et al. 1986; Tobin and Dolbeer 1990; Linz et al. 1991, 1998; Pain 1991). Knowledge of scavenging rates is therefore needed to ensure accurate estimates of pesticide-related mortality. Identification of predators and scavengers that feed on poisoned prey is needed to fully evaluate risks of secondary poisoning.

In the northern Great Plains, blackbirds (Icteridae) feed on ripening sunflower and cost producers millions of dollars (Linz and Hanzel 1997). Currently, the avicide DRC-1339 (3-chloro- $p$-toluidine HCl) (United States Department of Agriculture 1994) is used experimentally to bait blackbirds during spring migration in South Dakota (Barras 1996). Comprehensive study of carcass survival and potential secondary hazards involved with the use of DRC-1339 in the northern Great Plains is needed. Our objectives were 1) to determine carcass survival rates among habitat types and species of bird carcass and 2) to identify potential predators and scavengers, particularly raptors, of poisoned birds.

\section{METHODS}

In March and April, 1997 and 1998, we investigated survival rates of bird carcasses and risks of secondary poisoning at two sites, Arlington $\left(44^{\circ} 21^{\prime} \mathrm{N}, 97^{\circ} 08^{\prime} \mathrm{W}\right)$ and Ramona $\left(44^{\circ} 7^{\prime} \mathrm{N}, 97^{\circ} 12^{\prime} \mathrm{W}\right)$, in east-central South Dakota where DRC-1339 is being used to bait blackbirds in the spring (Barras 1996). These sites were chosen due to the presence of large ( $>$ 50,000 birds) blackbird roosts. Detailed descriptions of these sites are provided in Barras (1996).

To assess survival, carcasses were placed along a total of 46 transects in spring 1997 and 1998. Transects were placed in wooded, crop (bean or corn) stubble, roadside, and grassland habitats. Typically, there were 10 carcasses per transect. The first carcass along a transect was placed a randomly selected distance $(0-10 \mathrm{~m})$ into the habitat. Crop stubble and grassland habitat patches ranged in size from approximately $0.13-0.38$ hectares. Wooded and roadside habitat patches were at least 0.1 hectares in size. Remaining carcasses were systematically placed at 10-m intervals along transects. A small ribbon was placed approximately $1 \mathrm{~m}$ from carcasses to facilitate relocation. Carcasses consisted of blackbirds, European Starlings (Sturnis vulgaris), House Sparrows (Passer domesticus), Ringnecked Pheasants (Phasianus colchicus) and Rock Doves (Columba livia). Leather gloves and rubber boots were worn to reduce human scent on and near carcasses. The status of each carcass was checked daily for $5 \mathrm{~d}$. A carcass was recorded as intact if it was undisturbed and scavenged if it was eaten or removed. Carcass survival curves were generated by the product-limit life table method (Kaplan and Meier 1958) using the LIFETEST procedure in SAS (SAS Institute, Inc. 1990). To test the null hypothesis 
of no difference in survival rates among habitat types and species of carcass, survival curves were compared using a Wilcoxon test modified for censoring by Breslow (1970). A censored carcass in these analyses was any carcass still intact at the last check. All hypotheses were evaluated at the $P=0.05$ level.

In 1997, 7, 4, 2, and 2 transects (148 total carcasses) were placed in wooded, crop stubble, roadside, and grassland habitats, respectively. The carcasses consisted of 10 Common Grackles (Quisculus quiscula), $20 \mathrm{Eu}-$ ropean Starlings, 24 House Sparrows, 33 Red-winged Blackbirds (Agelaius phoeniceus), 26 Ring-necked Pheasants, and 35 Rock Doves. In 1998, 9, 8, 7 , and 7 transects (306 total carcasses) were placed in wooded, crop stubble, roadside, and grassland habitats, respectively. The carcasses consisted of 39 Common Grackles, 11 European Starlings, 52 House Sparrows, 92 Red-winged Blackbirds, 31 Ring-necked Pheasants, 51 Rock Doves, and 30 Yellow-headed Blackbirds (Xanthocephalus xanthocephalus). All carcasses were randomly placed along transects with the stipulation that there had to be at least two each of blackbird, house sparrow, ring-necked pheasant, and rock dove carcasses per transect. At any given time, between-transect distances were at least $0.13 \mathrm{~km}$ and were typically greater than $1 \mathrm{~km}$.

Olympus Infinity Mini DLX cameras $(n=20)$ connected to Trailmaster TM 1500 active infrared game monitoring systems were used to photograph predators and scavengers approaching live, caged birds used to simulate birds impaired by DRC-1339 and carcasses used to simulate birds killed by DRC-1339. Camera systems were placed in cropland, grassland, and wooded habitats. Due to the potential for human disturbance, camera systems were not placed in roadside habitat. In addition, camera systems were placed at abandoned farmsteads and wetland edges when possible, as these are habitats likely to harbor predators and scavengers and where poisoned birds are likely to be found. Cameras were operational $24 \mathrm{~h}$ per day, except under conditions of heavy rain or snow. Camera systems were checked daily to determine if there had been any predator or scavenger activity at the site, to feed and water live birds, and to ensure that camera systems were functioning properly. Carcasses were monitored for up to 5 d. In 1997 and 1998, respectively, we monitored 156 and 133 blackbird, European Starling, House Sparrow, Ring-necked Pheasant, and Rock Dove carcasses. Live birds were monitored for up to $3 \mathrm{~d}$. In 1997 and 1998, respectively, we monitored 24 and 68 live birds (blackbirds, European Starlings, House Sparrows, and Rock Doves). Live birds were held in small $(46 \times 46 \times 16 \mathrm{~cm}$; mesh size $0.64 \mathrm{~cm} \times 0.64 \mathrm{~cm}$ in 1997 and $1.27 \mathrm{~cm} \times 1.27 \mathrm{~cm}$ in 1998) hardware cloth cages fitted with two small wind shelters, a perch, and food and water containers.

\section{RESULTS}

In 1997, survival rates differed among habitat types $\left(\chi^{2}{ }_{3}=62.89, P<\right.$ $0.001)$. We found carcass removal rates were highest in wooded habitats, with survival time averaging $2.1 \mathrm{~d}$ (Table 1). Mean longevity of carcasses 
TABLE 1. Cumulative daily percentages $( \pm$ SE) of bird carcasses scavenged by habitat in 1997 and 1998, South Dakota.

\begin{tabular}{lrcccc}
\hline \hline & \multicolumn{5}{c}{ Cumulative percentage scavenged } \\
\cline { 2 - 5 } Habitat & Day 1 & Day 2 & Day 3 & Day 4 & Day 5 \\
\hline 1997 & & & & \\
Wooded & $38 \pm 6 \%$ & $71 \pm 5 \%$ & $86 \pm 4 \%$ & $91 \pm 4 \%$ & $93 \pm 3 \%$ \\
Grassland & $10 \pm 7 \%$ & $15 \pm 8 \%$ & $20 \pm 9 \%$ & $30 \pm 10 \%$ & $35 \pm 11 \%$ \\
Roadside & $10 \pm 7 \%$ & $10 \pm 7 \%$ & $15 \pm 8 \%$ & $45 \pm 11 \%$ & $55 \pm 11 \%$ \\
Crop stubble & $5 \pm 4 \%$ & $18 \pm 6 \%$ & $23 \pm 7 \%$ & $26 \pm 7 \%$ & $41 \pm 8 \%$ \\
1998 & & & & & \\
Wooded & $20 \pm 4 \%$ & $47 \pm 5 \%$ & $58 \pm 5 \%$ & $68 \pm 5 \%$ & $78 \pm 4 \%$ \\
Grassland & $30 \pm 6 \%$ & $43 \pm 6 \%$ & $55 \pm 6 \%$ & $61 \pm 6 \%$ & $67 \pm 6 \%$ \\
Roadside & $23 \pm 5 \%$ & $31 \pm 6 \%$ & $50 \pm 6 \%$ & $54 \pm 6 \%$ & $57 \pm 6 \%$ \\
Crop stubble & $17 \pm 4 \%$ & $32 \pm 5 \%$ & $50 \pm 6 \%$ & $58 \pm 6 \%$ & $66 \pm 5 \%$ \\
\hline
\end{tabular}

in the other habitat types was slightly more than $4.2 \mathrm{~d}$. Species of carcass did not affect time to removal $\left(\chi^{2}{ }_{3}=1.95, P=0.86\right.$; Table 2$)$, which ranged from 2.3 (Common Grackle) to 3.5 (Red-winged Blackbird) d.

In 1998, survival rates did not differ $\left(\chi^{2}{ }_{3}=4.33, P=0.23\right)$ among habitat types, ranging from 3.1 to $3.4 \mathrm{~d}$ (Table 1). Likewise, species of carcass did not affect $\left(\chi^{2}{ }_{3}=8.5, P=0.20\right)$ carcass longevity (Table 2$)$, which ranged from 3.0 (Yellow-headed Blackbird) to 4.4 (European Starling) $d$.

In 1997, predator and scavenger activity was high, with $76 \%$ of the carcasses $(n=156)$ monitored with cameras being scavenged. Predators visited 17 of $24(71 \%)$ live birds. In comparison, only $55 \%$ of the carcasses $(n=133)$ were scavenged in 1998 , and $44 \%$ of the live birds $(n=68)$ were visited by predators.

Across years, 165 mammals and 39 birds were identified on film. Skunks, raccoons (Procyon lotor), and dogs (Canis domesticus) were the most common mammals identified, accounting for $51 \%, 16 \%$, and $8 \%$, respectively, of the animals photographed (Tables 3, 4). Red-tailed Hawks (Buteo jamaicensis) were identified 13 times followed by Northern Harriers (Circus cyaneus), Great Horned Owls (Bubo virginianus), and American Crows (Corvus brachyrhynchos), each of which was identified six or fewer times.

\section{DISCUSSION}

Carcass disturbance was higher in 1997 than in 1998 in wooded areas. High scavenging activity in 1997 was most likely related to $40 \%$ colder temperatures and 35\% higher precipitation than in 1998 (South Dakota Cooperative Extension Services 1997, 1998). During adverse weather, wooded areas can provide protected sites for foraging (Cassel and Wiehe 1980). Our data indicate that the kind of species does not affect carcass longevity, suggesting that scavengers find carcasses opportunistically. 
TABLE 2. Cumulative daily percentages ( \pm SE) of specific bird carcasses scavenged in 1997 and 1998, South Dakota.

\begin{tabular}{|c|c|c|c|c|c|}
\hline \multirow{2}{*}{$\begin{array}{c}\text { Species } \\
\text { (number of carcasses) }\end{array}$} & \multicolumn{5}{|c|}{ Cumulative percentage scavenged } \\
\hline & Day 1 & Day 2 & Day 3 & Day 4 & Day 5 \\
\hline \multicolumn{6}{|l|}{1997} \\
\hline House Sparrow $(n=24)$ & $25 \pm 9 \%$ & $50 \pm 10 \%$ & $54 \pm 10 \%$ & $71 \pm 9 \%$ & $79 \pm 8 \%$ \\
\hline Common Grackle $(n=10)$ & $30 \pm 14 \%$ & $40 \pm 15 \%$ & $50 \pm 16 \%$ & $50 \pm 16 \%$ & $50 \pm 16 \%$ \\
\hline European Starling $(n=20)$ & $20 \pm 9 \%$ & $40 \pm 11 \%$ & $60 \pm 11 \%$ & $65 \pm 11 \%$ & $65 \pm 11 \%$ \\
\hline Ring-necked Pheasant $(n=26)$ & $19 \pm 7 \%$ & $42 \pm 10 \%$ & $54 \pm 10 \%$ & $58 \pm 10 \%$ & $65 \pm 9 \%$ \\
\hline Rock Dove $(n=35)$ & $20 \pm 7 \%$ & $43 \pm 8 \%$ & $49 \pm 8 \%$ & $60 \pm 8 \%$ & $71 \pm 8 \%$ \\
\hline Red-winged Blackbird $(n=33)$ & $21 \pm 7 \%$ & $33 \pm 8 \%$ & $42 \pm 9 \%$ & $52 \pm 9 \%$ & $58 \pm 9 \%$ \\
\hline \multicolumn{6}{|l|}{1998} \\
\hline House Sparrow $(n=50)$ & $18 \pm 5 \%$ & $36 \pm 7 \%$ & $48 \pm 7 \%$ & $52 \pm 7 \%$ & $60 \pm 7 \%$ \\
\hline Common Grackle $(n=38)$ & $18 \pm 6 \%$ & $47 \pm 8 \%$ & $61 \pm 8 \%$ & $63 \pm 8 \%$ & $68 \pm 8 \%$ \\
\hline European Starling $(n=11)$ & $0 \pm 0 \%$ & $10 \pm 9 \%$ & $20 \pm 13 \%$ & $30 \pm 14 \%$ & $40 \pm 15 \%$ \\
\hline Ring-necked Pheasant $(n=31)$ & $16 \pm 7 \%$ & $26 \pm 8 \%$ & $48 \pm 9 \%$ & $61 \pm 9 \%$ & $65 \pm 9 \%$ \\
\hline Rock Dove $(n=51)$ & $27 \pm 6 \%$ & $47 \pm 7 \%$ & $59 \pm 7 \%$ & $65 \pm 7 \%$ & $73 \pm 6 \%$ \\
\hline Red-winged Blackbird $(n=91)$ & $27 \pm 5 \%$ & $37 \pm 5 \%$ & $54 \pm 7 \%$ & $63 \pm 7 \%$ & $68 \pm 5 \%$ \\
\hline Yellow-headed Blackbird $(n=28)$ & $21 \pm 8 \%$ & $46 \pm 9 \%$ & $61 \pm 9 \%$ & $71 \pm 9 \%$ & $82 \pm 7 \%$ \\
\hline
\end{tabular}


TABLE 3. Scavengers of bird carcasses in 1997 and 1998, South Dakota.

\begin{tabular}{lrrr}
\hline \hline & \multicolumn{3}{c}{ Number of individuals } \\
\cline { 2 - 4 } \multicolumn{1}{c}{ Scavenger species } & 1997 & 1998 & Total \\
\hline Mammals & & & \\
Badger (Taxidea taxus) & 1 & 0 & 1 \\
Cat (Felis sylvestris) & 1 & 3 & 4 \\
Dog (Canis domesticus) & 0 & 3 & 3 \\
Raccoon (Procyon lotor) & 4 & 13 & 17 \\
Striped skunk (Mephitis mephitis) & 58 & 25 & 83 \\
Thirteen-lined ground squirrel & 1 & 0 & 1 \\
$\quad$ (Sphermophilus tridecemlineatus) & 65 & 44 & 109 \\
Total mammals & & & \\
Birds & 0 & 1 & 1 \\
Sharp-shinned Hawk (Accipiter striatus) & 2 & 4 & 6 \\
Northern Harrier (Circus cyaneus) & 2 & 4 & 6 \\
Red-tailed Hawk (Buteo jamaicensis) & 7 & 0 & 7 \\
American Crow (Corvus brachyrhynchos) & 11 & 9 & 20 \\
Total Birds & 47 & 24 & 71 \\
Unknown scavenger & 37 & 60 & 97 \\
No scavenger & & & \\
\hline
\end{tabular}

Scavenging rates in our study are comparable to other reported data (Humberg et al. 1983; Stutzenbaker et al. 1986; Tobin and Dolbeer 1990; Linz et al. 1998). But scavenging rates can be expected to vary locally (Rosene and Lay 1963; Stutzenbaker et al. 1986; Tobin and Dolbeer 1990; Linz et al. 1991, 1998). In general, 10-50\% of carcasses are reported as

TABle 4. Potential predators of live birds in 1997 and 1998, South Dakota.

\begin{tabular}{lrrr}
\hline \hline \multirow{2}{*}{$\quad r$} & \multicolumn{3}{c}{ Number of individuals } \\
\cline { 2 - 4 } Predator species & 1997 & 1998 & Total \\
\hline Mammals & 0 & 3 & \\
Cat (Felis sylvestris) & 2 & 12 & 14 \\
Dog (Canis domesticus) & 0 & 1 & 1 \\
Mink (Mustela vison) & 6 & 10 & 16 \\
Raccoon (Procyon lotor) & 11 & 11 & 22 \\
Striped skunk (Mephitis mephitis) & 19 & 37 & 56 \\
Total mammals & & & \\
Birds & 1 & 3 & 4 \\
Cooper's Hawk (Accipiter cooperii) & 0 & 1 & 1 \\
Northern Harrier (Circus cyaneus) & 0 & 7 & 7 \\
Red-tailed Hawk (Buteo jamaicensis) & 1 & 0 & 1 \\
Long-eared Owl (Asio otus) & 1 & 5 & 6 \\
Great Horned Owl (Bubo virginianus) & 3 & 16 & 19 \\
Total birds & 9 & 38 & 47 \\
No predator & & & \\
\hline
\end{tabular}


scavenged after $1 \mathrm{~d}$. Researchers have considered such scavenging rates to be high.

Carcass survival rates have inherent unavoidable biases (Linz et al. 1998). For example, scavengers could have followed human trails to carcasses, and the ribbon used to mark the location of carcasses may have attracted curious scavengers. Alternately, trap-shy scavengers may have avoided carcasses or areas tainted with human scent. Ultimately, attraction to or avoidance of carcasses or areas tainted with human scent is probably dependent on the species of scavenger.

Mammals were by far the most commonly photographed predators and scavengers in our study. Mammals are known to be tolerant (i.e., LD $_{50}$ values typically greater than $100 \mathrm{mg} / \mathrm{kg}$ ) of DRC-1339 (United States Department of Agriculture 1994); therefore, secondary hazards to mammals are probably low, despite high levels of activity at carcasses and live birds. In general, secondary hazards to avian predators and scavengers are also low. Only a small number $(n=39)$ of avian predators and scavengers were photographed. In addition, most avian predators and scavengers are tolerant (i.e., $\mathrm{LD}_{50}$ values typically greater than $100 \mathrm{mg} / \mathrm{kg}$ ) of DRC-1339 (Johnston et al. 1999).

Even so, a few animals may be at risk. Cats (Felis sylvestris) and owls may be prone to acute poisoning by DRC-1339 (Felsenstein et al. 1974; Cunningham et al. 1979). Barn Owls (Tyto alba) have a $\mathrm{LD}_{50}$ value of 4.2 $\mathrm{mg} / \mathrm{kg}$ (Cunningham et al. 1979; Schafer et al. 1983; Knittle 1989). Little is known about the toxicity of DRC-1339 to strigid owls. The American Crow is sensitive to DRC-1339 (USDA 1994). To date, the only documented case of secondary poisoning by DRC-1339 has been in American Crows (Kreps 1974). However, most sensitive species would have to feed primarily on DRC-1339-poisoned birds for greater than $30 \mathrm{~d}$ or eat 2-3 times their body weight in DRC-1339 poisoned birds at a single feeding to experience acute or chronic poisoning (Cunningham et al. 1979).

Scavenger activity in east-central South Dakota during March and April 1997 and 1998 was high. Thus, it is critical that searches for animals be conducted within $24 \mathrm{~h}$ of the pesticide application. We recommend the use of trained dogs as a means to increase the efficiency of recovering poisoned birds in situations where nontarget and target mortality associated with pesticide use needs to be assessed (Homan et al. 2001). Since carcass survival differed among habitat types and years, it is necessary to assess scavenger activity by habitat type and on a yearly basis to ensure accurate indices of scavenging pressure.

Our data, combined with residue analyses in controlled studies, indicate that secondary hazards associated with the use of DRC-1339-avicide are minimal. That is, the majority of animals photographed at carcasses and at cages of live birds were tolerant of DRC-1339. Future research should focus on the chronic poisoning of strigid owls, a potentially sensitive group of species (Cunningham et al. 1979). In particular, attention should be given to nestlings of species such as the Great Horned Owl that are present during the DRC-1339 baiting period. 


\section{ACKNOWLEDGMENTS}

We thank those who assisted with the field phase of our project. Robert Carlson and Curt Doetkott provided advice on statistical analysis. Several private landowners in east-central South Dakota allowed access to their land for this study. Pheasant carcasses were obtained from Wayne Imel, Ingall's Prairie Wildfowl Hunt, Inc., and Dan Koepp. Protocol for use of live birds was approved by the Animal Care and Use Committee, United States Department of Agriculture Animal and Plant Health Inspection Service's Wildlife Services program. C. Ray Chandler, Mark Lutman, Rich Sawin, and several anonymous reviewers provided constructive criticism on this manuscript. Field work was conducted under the auspices of National Wildlife Research Center study protocol QA-437 and was conducted by the senior author in partial fulfillment of a M.Sc. degree in the Department of Zoology at North Dakota State University.

\section{LITERATURE CITED}

BALсOмB, R. 1986. Songbird carcasses disappear rapidly from agricultural fields. Auk 103: $817-820$.

BARRAS, A. E. 1996. Evaluation of spring baiting with an avicide, DRC-1339, and habitat preferences of migratory blackbirds. M.Sc. thesis. North Dakota State University, Fargo, North Dakota.

Breslow, N. 1970. A generalized Kruskal-Wallis test for comparing K samples subject to unequal patterns of censorship. Biometrika 57:579-594.

CASSEL, J. F., AND J. M. WiehE. 1980. Uses of shelterbelts by birds. Pp. 78-87, in R. M. DeGraff, and N. G. Tilghman, compilers. Workshop proc., management of western forests and grasslands for nongame birds. U.S. Department of Agriculture Forest Service General Technical Report INT-86, Ogden, Utah.

Cunningham, D. J., E. W. Schafer, JR., AND L. K. MCConnell. 1979. DRC-1339 and DRC2698 residues in starlings: preliminary evaluation of their effects on secondary hazard potential. Proc. Bird Control Sem. 8:31-37.

Felsenstein, W. C., R. P. Smith, And R. E. Gosselin. 1974. Toxicologic studies on the avicide 3-chloro-p-toluidine. Toxicol. Appl. Pharmacol. 28:110-125.

Homan, H. J., G. M. Linz, AND B. D. Peer. 2001. Dogs enhance recovery of passerine carcasses in dense vegetation. Wildl. Soc. Bull. 29: in press.

HumberG, D. D., D. Graber, AND S. SherifF. 1983. Estimating autumn-spring waterfowl nonhunting mortality in north Missouri. Trans. North Am. Wildl. Nat. Resour. Conf. 48:241256.

Johnston, J. J., D. B. Hurlbut, M. L. Avery, and J. C. Rhyan. 1999. Methods for the diagnosis of acute 3-chloro-p-toluidine hydrochloride poisoning in birds and the estimation of secondary hazards to wildlife. Environ. Toxicol. Chem. 18:2533-2537.

KaPlan, E. L., AND P. MEIER. 1958. Nonparametric estimation from incomplete observations. J. Am. Stat. Assoc. 53:457-481.

KNITTLE, C. E. 1989. Summary of currently available avian single-dose oral $\mathrm{LD}_{50}$ data for the chemical 3-chloro-4-methylbenzenamine hydrochloride (Compound DRC-1339; CPTH). U.S. Department of Agriculture Animal Plant Health Inspection Service, Denver Wildlife Research Center Unpubl. Special Report Vol. 2, Denver, Colorado.

KrePS, L. B. 1974. Feral pigeon control. Proc. Vertebr. Pest Conf. 6:257-262.

LinZ, G. M., D. L. BERGMAN, AND W. J. BLEIER. 1998. Estimating survival of songbird carcasses in crops and woodlots. Prairie Nat. 29:7-13.

, J. E. Davis, JR., R. M. Engeman, D. L. Otis, And M. L. Avery. 1991. Estimating survival of bird carcasses in cattail marshes. Wildl. Soc. Bull. 19:195-199.

— flower science and technology. American Society of Agronomy, Madison, Wisconsin.

PaIN, D. J. 1991. Why are lead-poisoned waterfowl rarely seen? The disappearance of waterfowl carcasses in the Camergue, France. Wildfowl 42:118-122.

Rosene, W., AND D. W. LAY. 1963. Disappearance and visibility of quail remains. J. Wildl. Manage. 27:139-142. 
SAS InstituTE, INC. 1990. SAS/STAT ${ }^{\circledR}$ user's guide, version 6, fourth ed., vol. 2. SAS Institute, Inc., Cary, NC.

Schafer, E. W., JR., W. A. Bowles, JR., And J. Hurlbut. 1983. The acute oral toxicity, repellency, and hazard potential of 998 chemicals to one or more species of wild and domestic birds. Arch. Environm. Contam. Toxicol. 12:355-382.

South Dakota Cooperative Extension Service (SDCES). 1997. 1997 climate summary. http://www.abs.sdstate.edu/ae/weather/T\&P_1997.htm.

. 1998. 1998 climate summary. http://www.abs.sdstate.edu/ae/weather/ T\&P_1998.htm.

Stutzennaker, C. D., K. Brown, And D. Lobpries. 1986. Special report: an assessment of the accuracy of documenting waterfowl die-offs in a Texas coastal marsh. Pp. 88-95, in J. S. Feierabend, and A. B. Russell, eds. Lead poisoning in wild waterfowl, a workshop: symposium, March 3-4, 1984, Wichita, Kans. Cooperative Lead Poisoning Control Inf. Program, Washington, D.C.

Tobin, M. E., AND R. A. DolbeER. 1990. Disappearance and recoverability of songbird carcasses in fruit orchards. J. Field Ornithol. 61:237-242.

Tome, M. W., C. E. Glue, AND L. R. DeWeEse. 1991. Ethyl parathion in wetlands following aerial application to sunflower in North Dakota. Widl. Soc. Bull. 19:450-457.

United States Department of Agriculture (USDA). 1994. Final environmental impact statement, Appendix P: Risk assessment of wildlife damage control methods used by the USDA Animal Damage Control program. U. S. Department of Agriculture, Animal Plant Health Inspection Service, Washington, D.C.

Received 9 February 2000; accepted 1 December 2000. 